\title{
Direct contribution of clams (Ruditapes philippinarum) to benthic fluxes, nitrification, denitrification and nitrous oxide emission in a farmed sediment
}

David T. Welsh" ${ }^{1, *}$, Daniele Nizzoli ${ }^{2}$, Elisa A. Fano ${ }^{3}$, Pierluigi Viaroli ${ }^{2,4}$

1 School of Environment and Environmental Futures Centre, Griffith University, Gold Coast Campus, Queensland 4222 Australia.

2 Department of Life Sciences, University of Parma, Viale delle Scienze 11A, I-43124 Parma, Italy.

3 Department of Life Sciences and Biotechnology, University of Ferrara, Via Luigi Borsari 46, I-44100 Ferrara, Italy.

4 CNR-ISMAR, Arsenale - Tesa 104, Castello 2737/F, I-30122 Venezia, Italy.

Corresponding author. Tel: +61 (0)7 55529186

Fax: +61 (0)7 55528067

Email: d.welsh@griffith.edu.au

Keywords: Nitrous oxide; denitrification; nitrification; aquaculture; $R$. philippinarum; Manila clam 


\section{Abstract}

The influence of the manila clam (Ruditapes philippinarum) on processes and fluxes in a farmed sediment was investigated using a multiple core incubation approach and parallel incubations of individual clams. Clam population/biomass density varied $\sim 8$-fold between cores and all sediment-water column solute $\left(\mathrm{O}_{2} . \mathrm{N}_{2}, \mathrm{~N}_{2} \mathrm{O}, \mathrm{NH}_{4}{ }^{+}, \mathrm{NO}_{\mathrm{X}}\right.$ and DIN) fluxes and process (ammonification, nitrification and denitrification) rates were strongly and significantly correlated with clam density/biomass. Isolated clams exhibited high rates of respiration, N-excretion, nitrification and denitrification of 2,050 $\pm 70,395 \pm 49,201 \pm 42$ and $235 \pm 40 \mathrm{nmol}$ individual ${ }^{-1} \mathrm{~h}^{-1}$, respectively.

The direct contribution of the clams and their associated microbiota to benthic processes was estimated by multiplying the per individual rates by the number of clams in each incubated core. The clams on average directly accounted for $64-133 \%$ of total rates of sediment oxygen demand, ammonification, nitrification and denitrification, indicating that they regulated processes primarily through their own metabolic activity and that of bacteria that colonise them.

Clams and the farmed sediments were significant sources of the greenhouse gas $\mathrm{N}_{2} \mathrm{O}$, but this was primarily due to their high nitrification and denitrification rates, rather than high specific $\mathrm{N}_{2} \mathrm{O}$ yields, as $\mathrm{N}_{2} \mathrm{O}$ emissions represented $<1 \%$ of total $\mathrm{N}_{2} \mathrm{O}+\mathrm{N}_{2}$ production. The clam-farmed sediments had a high denitrification efficiency of $67 \pm 10 \%$, but this ecosystem service came at the environmental cost of increased $\mathrm{N}$-regeneration and $\mathrm{N}_{2} \mathrm{O}$ emission rates. The measured $\mathrm{N}_{2} \mathrm{O}$ emissions indicate that bivalve aquaculture may be a significant source of $\mathrm{N}_{2} \mathrm{O}$. It is therefore recommended that $\mathrm{N}_{2} \mathrm{O}$ emissions should be included in the impact assessments of current and future bivalve-farming projects. 


\section{Introduction}

Increased nutrient loads from urban and agricultural sources have resulted in a general eutrophication of coastal marine ecosystems (Heisler et al., 2008; Smith and Schindler, 2009; Canfield et al., 2010). Benthic nitrogen cycling and particularly denitrification and coupled nitrification-denitrification can ameliorate the impacts of nitrogen loading by eliminating bioavailable $\mathrm{N}$ as gaseous products (Herbert, 1999; Seitzinger at al., 2007). However, these processes are also "natural" sources of the greenhouse gas nitrous oxide $\left(\mathrm{N}_{2} \mathrm{O}\right)$, which is an intermediate in denitrification (Zumft, 1997) and a by-product of ammonium oxidation (so called nitrifier denitrification) during nitrification (Goreau et al., 1980; Poth \& Focht, 1985).

Benthic infauna can profoundly influence benthic N-cycling through their feeding, metabolic, burrow construction, bioturbation and sediment ventilation activities (Kristensen, 2000; Welsh, 2003; Stief, 2013). Fauna can greatly increase local organic matter inputs by directly trapping suspended particles from the water column during filter-feeding and depositing these in the sediment as faeces and pseudofaeces (see Graf \& Rosenberg, 1997 for review). Physical mixing (bioturbation) of the sediment transports organic matter into deeper sediment strata, influencing the pathways of organic matter mineralisation (Kristensen, 2000; Welsh, 2003). The construction of burrows increases the area of contact between the sediment and water column by up to 500\% promoting solute exchanges (Welsh, 2003; Stief, 2013). Burrow ventilation introduces oxygen from the overlying water leading to the development of oxic and suboxic sediment zones, which are amenable to nitrification and denitrification (Welsh, 2003; Nielsen et al., 2004; Robertson et al., 2009; Stief, 2013). These activities have been shown to enhance rates of benthic metabolism, nitrogen regeneration, nitrification and denitrification (Howe et al., 2004; Jordan et al., 2009; Dunn et al., 2009, 2012; Nizzoli et al., 2007, 2011). 
Recently, the hard surfaces, soft tissues and digestive systems of a diverse range of benthic marine infauna and epifauna have been shown to be colonised by nitrifying and/or denitrifying bacteria, or to exhibit high rates of these processes (Welsh \& Castadelli, 2004; Stief et al., 2009, 2010; Welsh et al., 2009: Heisterkamp et al., 2010, 2013: Radax et al., 2012; Keesing et al., 2013). Thus, the presence of fauna could directly contribute to local rates of nitrification and denitrification. Additionally, the contribution of $\mathrm{N}_{2} \mathrm{O}$ to total denitrification $\left(\mathrm{N}_{2} \mathrm{O}+\mathrm{N}_{2}\right.$ production) associated with fauna can be more than an order of magnitude greater than is typical of marine sediments (Stief et al., 2009; Heisterkamp et al., 2013). Consequently, whilst the presence of fauna may enhance rates of nitrogen elimination by stimulating nitrification and denitrification, they may preferentially enhance $\mathrm{N}_{2} \mathrm{O}$ emissions.

This impact may be greatest in areas utilised for the farming of filter-feeding bivalves, as these are often cultivated over large areas, at very high densities. Additionally, the shells and soft tissues of bivalves including some commercially cultivated species are known to be heavily colonised by N-cycling bacteria (Welsh and Castadelli, 2004; Nizzoli et al., 2006a; Stief et al., 2009; Heisterkamp et al., 2010, 2013) and to exhibit high $\mathrm{N}_{2} \mathrm{O}$ emission rates (Heisterkamp et al., 2010, 2013).

In this study we investigated the dependence of benthic fluxes, $\mathrm{N}$-cycle processes and $\mathrm{N}_{2} \mathrm{O}$ emissions on the population density of the manila clam (Ruditapes philippinarum) in a farmed area of the Sacca di Goro, Italy, using a multiple core incubation technique. In parallel, individual clams were incubated to determine their respiration and $\mathrm{N}$-excretion rates, and associated rates of nitrification, denitrification and $\mathrm{N}_{2} \mathrm{O}$ emission. These data were used to estimate the potential direct contribution of the clams to the core determined rates. The manila clam is a widely farmed bivalve with annual Worldwide production of $\sim 3.5$ million $\mathrm{t}$ in 2010 (FAO, 2013). 


\section{Methods}

\subsection{Study site}

The Sacca di Goro $\left(44^{\circ} 82^{\prime} \mathrm{N}, 12^{\circ} 27^{\prime} \mathrm{E}\right)$ is a small lagoon $\left(26 \mathrm{~km}^{2}\right)$ of the Po River Delta, Italy. The lagoon has a mean depth of $1.5 \mathrm{~m}$ and $~ 50 \%$ of the lagoon is licensed for farming of the manila clam R. philippinarum (Fig. 1.), with annual production estimated at $\sim 10,000$ to 15,000 t (Nizzoli et al., 2006b). Within the farmed zones clams are seeded throughout the year and local densities can be $>2000$ ind $\mathrm{m}^{-2}$ (Nizzoli et al., 2006b).The field site used for collection of cores and clams in this study was located in an intensively farmed area in the central part of the lagoon (Fig. 1.).

\subsection{Sample collection and core maintenance}

All sediment cores were hand collected on the $5^{\text {th }}$ December 2012 using Plexiglass core tubes. Ten sediment cores ( $\sim 10 \mathrm{~cm}$ sediment depth) were randomly collected using $30 \mathrm{x} 8$ (internal diameter) cm core tubes for determination of sediment water column solute fluxes, three sediment cores $(40 \times 20 \mathrm{~cm})$ were collected as a source of clams for the clam incubations and three cores $(20 \mathrm{x} 4 \mathrm{~cm})$ for determination of sediment characteristics.

Approximately $200 \mathrm{l}$ of site water was collected for core maintenance and incubation in the laboratory. Water column salinity and temperature were determined in situ using refractometer and thermometer, and water samples collected for determination of oxygen, $\mathrm{N}_{2} \mathrm{O}$ and nutrient concentrations.

Cores were returned to the laboratory within 3 hours of collection and submerged in a holding tank of aerated in situ water in a constant temperature room at in situ temperature (8 \pm $2{ }^{\circ} \mathrm{C}$ ). Water mixing within the $20 \mathrm{~cm}$ diameter cores was maintained using small aquarium pumps attached to the wall of the core tubes. Mixing in the $8 \mathrm{~cm}$ diameter cores was assured by small magnetic stirrers fitted within each core, which were driven by a large magnet 
rotated by an external motor at $40 \mathrm{rpm}$. Both sets of cores were allowed to stabilise overnight in the dark prior to incubations.

\subsection{Determination of sediment-water column solute fluxes}

Prior to the core incubations the water in the incubation tank was refreshed with fresh site water to maintain near in situ dissolved nutrient concentrations. The water within each individual core was then exchanged with the overlying water by repeatedly removing water from inside the core using a $100 \mathrm{ml}$ syringe whilst the core was still submerged. To initiate incubations, the water level in the tank was lowered to below the core tops, initial water samples were collected for the determination of dissolved nutrient and gas concentrations and the cores sealed with floating Plexiglass lids to prevent gaseous exchange with the atmosphere. Cores were incubated for 3 hours in the dark. This incubation time was chosen based on test incubations for $\mathrm{O}_{2}$ fluxes, in order to maintain the mean water column $\mathrm{O}_{2}$ concentration close to $80 \%$ of the initial saturation.

At the end of the incubation period, the floating lids were removed and water samples collected for the determination of final time dissolved nutrient and gas concentrations. Flux rates were calculated from the change in the water column concentration of each dissolved species as previously described (Welsh et al., 2000).

Process rates were estimated by mass balance by assuming that rates of nitrogen fixation were negligible, as the farmed sediments are constant large net sources of dissolved inorganic nitrogen (Nizzoli et al., 2006a \& b; 2011). This would lead to a dominance of denitrification over N-fixation (Fullweller et al., 2013), as for energetic considerations these fixed N-sources would be utilised in preference to dinitrogen gas (Fenchel et al., 1998). Therefore, we consider that the measured $\mathrm{N}_{2}$ and $\mathrm{N}_{2} \mathrm{O}$ fluxes provide an accurate measure of the denitrification rate. Dissimilatory nitrate reduction to ammonium (DNRA) was also 
considered to be a negligible process, which would have little impact on estimates of nitrification and ammonification rates, as previous measurements at an adjacent site using the isotope pairing technique found that DNRA accounted for less than 5\% of total nitrate reduction in winter (Nizzoli et al., 2006a). Individual process rates were calculated from the measured flux rates as follows:

Denitrification $=\mathrm{N}_{2}$ flux $+\mathrm{N}_{2} \mathrm{O}$ flux

Nitrification $=\mathrm{NO}_{\mathrm{X}}$ flux $+\mathrm{N}_{2}$ flux $+\mathrm{N}_{2} \mathrm{O}$ flux

Ammonification $=\mathrm{NH}_{4}^{+}$flux $+\mathrm{NO}_{\mathrm{X}}$ flux $+\mathrm{N}_{2}$ flux $+\mathrm{N}_{2} \mathrm{O}$ flux

Sediment denitrification efficiency was calculated from the estimated denitrification and ammonification rates as:

Denitrification efficiency $=$ denitrification/ammonification $* 100$

At the end of the incubations each core was sieved through a $1 \mathrm{~mm}$ mesh, the clams counted and retained for determination of fresh weight and dry flesh weight.

\subsection{Determination of clam respiration and $\mathrm{N}$-excretion rates, $\mathrm{N}$-process rates and $\mathrm{N}_{2} \mathrm{O}$ emissions}

Approximately 1 hour prior to the experiment, clams were harvested by sieving from the $20 \mathrm{~cm}$ diameter cores and gently rinsed to remove adhering sediment. Median sized individuals $(11.0 \pm 1.9 \mathrm{~g}$ fresh weight; $\mathrm{n}=5)$ were transferred to $192 \mathrm{ml}$ jars. The jars were completely filled with aerated site water and sealed using watch glasses, taking care not to trap air bubbles. Triplicate samples of the incubation water were collected for determination of initial dissolved nutrient and gas concentrations. Clams were incubated for 6 hours at in situ temperature in the dark in a constant temperature room. At the end of the incubations, the 
watch glasses were removed and water samples immediately collected for determination of final time dissolved nutrient and gas concentrations. Oxygen concentrations at the end of the incubations remained above 50\% (range 53-63\%) of the initial concentration of $305.4 \mu \mathrm{M}$ in all replicates. The incubated clams were retained for determination of flesh dry weight.

Solute production/consumption rates were determined from the change in the concentration and standardised per individual or unit biomass. Nitrification and denitrification rates were calculated by mass balance as described in section 2.3., nitrogen excretion rates as:

$$
\mathrm{N} \text {-excretion }=\mathrm{NH}_{4}^{+} \text {flux }+\mathrm{NO}_{\mathrm{X}} \text { flux }+\mathrm{N}_{2} \text { flux }+\mathrm{N}_{2} \mathrm{O} \text { flux }
$$

\subsection{Sample handling and analytical methods}

All water samples were collected using acid washed, site water rinsed tubing and $50 \mathrm{ml}$ syringes, taking care to avoid bubble formation. Samples for dissolved nutrient analyses were immediately filtered (GF/F, Whatman) and stored frozen until analysed. Dissolved gas samples were transferred to air tight, completely filled glass vials (Exetainer, Labco Ltd.) and fixed with either $100 \mu \mathrm{l}$ of manganous sulfate and alkali-iodide-azide (APHA, 1998) for oxygen determinations or $150 \mu \mathrm{l} 7 \mathrm{M} \mathrm{ZnCl}_{2}\left(\mathrm{~N}_{2}\right.$ and $\mathrm{N}_{2} \mathrm{O}$ samples) and stored at $4{ }^{\circ} \mathrm{C}$ until analysed. Dissolved oxygen concentrations were determined by the Winkler method (APHA 1998); $\mathrm{NH}_{4}{ }^{+}$by the indophenol blue method according to Bower \& Hansen, (1980). NOx was determined by diazotation, after reduction to nitrite over cadmium columns (APHA, 1998). $\mathrm{N}_{2} \mathrm{O}$ was determined following the headspace equilibration technique using a gas chromatograph (Thermo Finnigan Trace GC,) equipped with an ECD detector operated at $350^{\circ} \mathrm{C}$ and a poraPLOT-Q column (32 m long x $0.32 \mathrm{~mm}$ internal diameter). Samples were equilibrated at $30^{\circ} \mathrm{C}$ for 24 hours prior to the injection of $0.25 \mathrm{ml}$ of gas into the GC. $\mathrm{N}_{2}$ was determined from $\mathrm{N}_{2}$ :Ar ratios measured by membrane inlet mass spectrometry (MIMS) according to Kana et al. (1994) using a PrismaPlus mass spectrometer with an in line furnace 
operated at $600{ }^{\circ} \mathrm{C}$ to allow for $\mathrm{O}_{2}$ removal. All measured dissolved solute concentrations were significantly greater than the respective assay detection limits. Precision at the relevant concentration ranges, estimated as the relative standard deviation of 5 replicate analyses of the site water used for all incubations were $0.54 \%$ (oxygen), 3.7\% $\left(\mathrm{NH}_{4}{ }^{+}\right), 1.40 \%\left(\mathrm{NO}_{\mathrm{X}}\right), 0.65 \%$ $\left(\mathrm{N}_{2}\right)$ and $5.03 \%\left(\mathrm{~N}_{2} \mathrm{O}\right)$.

The organic matter content of the upper $2 \mathrm{~cm}$ of sediment was determined by the Loss On Ignition (LOI $\left.{ }_{550}\right)$ method as described by Nizzoli et al., 2005 and clam flesh dry weight as described by Bartoli et al., 2001.

\subsection{Statistical analyses}

The density dependence of flux and N-cycle process rates was investigated using regression models between the clam dry flesh weight measured in each core and the flux and estimated process rates in the same core. All analyses where performed using Sigma Plot statistical package (SygmaPlot 11.0, Systat).

\section{Results}

\subsection{Water column and sediment physicochemical characteristics, and clam densities}

The farmed sediment was composed of medium to course sands with a moderate organic matter content of $3.02 \pm 0.04\left(\mathrm{LOI}_{550}\right)$. Water temperature was $8{ }^{\circ} \mathrm{C}$ and salinity $25 \%$, and water column concentrations of $\mathrm{NH}_{4}{ }^{+}$and $\mathrm{NO}_{\mathrm{X}}$ were $18.7 \pm 0.7$ and $69.9 \pm 1.0 \mu \mathrm{M}$, respectively. The in situ dissolved oxygen concentration was $304 \pm 0.2 \mu \mathrm{M}$ (97\% saturation) and the dissolved $\mathrm{N}_{2} \mathrm{O}$ concentration was $24 \pm 1 \mathrm{nM}(\sim 200 \%$ saturation).

The density of the cultivated clams was $1440 \pm 313$ individuals $\mathrm{m}^{-2}$, equivalent to $7540 \pm$ $1485 \mathrm{~g} \mathrm{FW} \mathrm{m}^{-2}$. The clam populations, however were patchily distributed with population 
density, fresh weight and dry flesh weight biomass all varying by $\sim 8$-fold between the individual cores (Table 2.). Thus, the cores represented an appropriate, large range of clam density/biomass for determination of relationships with benthic flux and process rates.

\subsection{Density dependence of benthic fluxes and $N$-cycle processes}

The results of the statistical analyses of correlations between sediment-water column flux and estimated N-cycle process rates, and clam populations were highly similar whether the clam population data was expressed as number of individuals, g total fresh weight or $\mathrm{g}$ flesh dry weight biomass $\mathrm{m}^{-2}$. Therefore, in the subsequent sections data are presented only for correlations with dry flesh weight biomass $\mathrm{m}^{-2}$.

Benthic oxygen fluxes varied between -575 and $-7268 \mu \mathrm{mol} \mathrm{m}{ }^{-2} \mathrm{~h}^{-1}$ and showed a strong, significant correlation with clam biomass (Table 2; Fig. 2). Sediment-water column fluxes of all dissolved inorganic nitrogen (DIN) species were all positive (Fig. 2.) and significantly correlated with clam biomass (Table 2). $\mathrm{NH}_{4}{ }^{+}$fluxes in the individual cores ranged from 39 to $614 \mu \mathrm{mol} \mathrm{m} \mathrm{m}^{-2} \mathrm{~h}^{-1}$ and were positively correlated with clam biomass (Fig. 2.). Sediment water column $\mathrm{NO}_{\mathrm{X}}$ fluxes exhibited a significant negative correlation with the clam biomass (Table 2.), with $\mathrm{NO}_{\mathrm{X}}$ effluxes measured in cores with low clam biomass, whereas the sediments were strong sinks for $\mathrm{NO}_{\mathrm{X}}$ in cores with higher clam biomass (Fig. 2.).

All estimated $\mathrm{N}$-cycle process rates were also significantly correlated with clam biomass (Table 2). Mass balance estimates of ammonification rates ranged between 279 and 1255 $\mu \mathrm{mol} \mathrm{m} \mathrm{m}^{-2} \mathrm{~h}^{-1}$ (Fig. 3.) and were significantly and strongly correlated with clam biomass. Nitrification rates exhibited the same trend with the estimated rates increasing with and being significantly correlated to the clam biomass in the same incubation core (Table 2; Fig. 3.). Sediment-water column fluxes of both $\mathrm{N}_{2}$ and $\mathrm{N}_{2} \mathrm{O}$ were both positively correlated with clam biomass (Table 2; Fig. 3.). Sediment $\mathrm{N}_{2} \mathrm{O}$ emissions represented $0.11-0.18 \%$ of total 
denitrification products $\left(\mathrm{N}_{2}+\mathrm{N}_{2} \mathrm{O}\right)$, but the $\% \mathrm{~N}_{2} \mathrm{O}$ yield showed no significant correlation with clam biomass ( $p>0.05$; data not shown). Mass balance estimates of denitrification rates for each individual incubation core ranged from 165 to $826 \mu \mathrm{mol} \mathrm{N} \mathrm{m}{ }^{-2} \mathrm{~h}^{-1}$ and demonstrated a strong significant positive correlation with the clam biomass (Table 2.). Sediment denitrification efficiency was high (mean $67.2 \pm 9.9 \%$; $n=10$ ) but showed no significant correlation with clam density (Table 2.).

\subsection{Solute production/consumption and microbial process rates associated with isolated} clams

Solute exchange and estimated N-cycle process rates directly associated with isolated clams are shown on a per individual, per gram fresh weight biomass and per gram dry flesh weight biomass basis in Table 3. Clams were a large sinks for oxygen and net sources of DIN $\left(159.7 \pm 10.3 \mathrm{nmol}\right.$ individual $\left.{ }^{-1} \mathrm{~h}^{-1}\right)$ due to a net consumption of $34.9 \pm 1.9 \mathrm{nmol}$ individual ${ }^{-1}$ $\mathrm{h}^{-1}$ of $\mathrm{NO}_{\mathrm{x}}$ and net production of $193.9 \pm 8.8 \mathrm{nmol} \mathrm{NH}_{4}{ }^{+}$individual ${ }^{-1} \mathrm{~h}^{-1}$. The measured net $\mathrm{NO}_{\mathrm{x}}$ consumption was however only sufficient to support $\sim 15 \%$ of the denitrification rate of $234.9 \pm 40.4$ nmol $\mathrm{N}$ individual ${ }^{-1} \mathrm{~h}^{-1}$, requiring a further mean input of $\mathrm{NO}_{\mathrm{x}}$ of $200.7 \pm 40.3$ nmol individual ${ }^{-1} \mathrm{~h}^{-1}$ from nitrification to achieve mass balance. Mass balance calculations also indicated a clam total $\mathrm{N}$-excretion rate of $394.7 \pm 49.1 \mathrm{nmol} \mathrm{N}$ individual ${ }^{-1} \mathrm{~h}^{-1}$ and therefore, the net DIN production of $159.7 \pm 10.3 \mathrm{nmol}$ individual ${ }^{-1} \mathrm{~h}^{-1}$ represented only $40.5 \%$ of $\mathrm{N}$ excreted by the clams with the remainder having being nitrified and denitrified.

Clams were also sources of $\mathrm{N}_{2} \mathrm{O}\left(1.9 \pm 0.4 \mathrm{nmol} \mathrm{N}\right.$ individual $\left.{ }^{-1} \mathrm{~h}^{-1}\right)$ which accounted for $0.95 \pm 0.28 \%$ of total denitrification products.

\subsection{Potential contribution of clams to overall benthic process rates}


In order to evaluate the potential contribution of clam associated processes to the overall benthic process rates in the incubation cores, the per individual rates of oxygen consumption, $\mathrm{N}$-excretion, nitrification, denitrification, and $\mathrm{N}_{2}$ and $\mathrm{N}_{2} \mathrm{O}$ production shown in Table 3 were multiplied by the number of clams present in each individual core to estimate a "clams alone" rate and the \% contribution of this rate to the total rate measured in the same core calculated. Average rates for all core incubations, estimated “clams alone” rates for the same cores and the average \% contribution of the clams to the whole core rates are presented in Fig. 4.

Oxygen consumption by the clams could account for 70 to $281 \%$ of the overall sediment oxygen demand determined in each core, and on average $133 \pm 22 \%$ of the mean SOD of $3013 \pm 693 \mu \mathrm{mol} \mathrm{m} \mathrm{m}^{-2} \mathrm{~h}^{-1}$. Clam N-excretion rates accounted for 44 to $117 \%$ of the estimated ammonification rate in each core and represented on average $80 \pm 7 \%$ of the mean benthic ammonification rate of $711 \pm 108 \mu \mathrm{mol} \mathrm{m} \mathrm{m}^{-2} \mathrm{~h}^{-1}$. Similarly, denitrification rates associated with the clams could account for 42 to 86 (mean $70 \pm 5$ ) \% of the mean benthic denitrification rate of $468 \pm 66 \mu \mathrm{mol} \mathrm{N} \mathrm{m} \mathrm{N}^{-2} \mathrm{~h}^{-1}$, with clam associated production rates of $\mathrm{N}_{2}$ and $\mathrm{N}_{2} \mathrm{O}$ production accounting for on average $70 \pm 5$ and $241 \pm 195 \%$ respectively, of the core measured sediment-water column $\mathrm{N}_{2}$ and $\mathrm{N}_{2} \mathrm{O}$ effluxes.

Estimated rates of nitrification associated with the clams also accounted for 28 to $92 \%$ of the sediment nitrification rates estimated by mass balance for each individual core and for an average of $64 \pm 5 \%$ of the mean sediment nitrification rate of $429 \pm 50 \mu \mathrm{mol} \mathrm{N} \mathrm{m} \mathrm{N}^{-2}$.

\section{Discussion}

\subsection{Density dependence of benthic fluxes and $\mathrm{N}$-cycle processes}

Mean sediment-water column fluxes of oxygen, net DIN, all individual N-species and mass balance estimates of $\mathrm{N}$-cycle process rates were all high in the clam-farmed sediments, as has been consistently observed in other studies of clam-farmed sediments in the Sacca di Goro 
lagoon (Nizzoli et al., 2006a \& b, 2011). All flux and estimated process rates showed highly significant correlations with clam biomass density. These data clearly demonstrate that clams exerted a major influence on benthic process rates and sediment-water column exchanges of oxygen and DIN species. It would be expected that clams would exert a major influence on sediment biogeochemistry, especially at the high densities that occur in the farmed sediments, as filter-feeding organisms can increase organic matter deposition rates by more than an order of magnitude (Graf \& Rosenberg, 1997). The organic matter harvested from the water column by the clams would fuel oxygen consumption and the associated regeneration of inorganic nutrients by their own metabolism leading to a correlation between clam biomass density, and overall benthic respiration and nitrogen regeneration rates. Additionally, the clams may also influence microbial oxygen consumption and nutrient regeneration rates in their vicinity due to localised deposition of faeces and pseudo-faeces.

In addition to influencing rates of organic matter turnover in the sediment by enhancing inputs of particulate organic matter, fauna through their bioturbation and bioirrigation activities can influence pathways of $\mathrm{C}$ and $\mathrm{N}$-cycling by changing the conditions under which remineralisation takes place (Kristensen, 2000; Welsh, 2003; Stief 2013). In this study estimated benthic nitrification and denitrification rates were significantly correlated to the biomass density of clams. Benthic infauna have been proposed to enhance rates of nitrification by increasing the volume of oxic sediment amenable to ammonium oxidation by forming burrows and irrigating these with oxygenated water (Satoh et al., 2007; Stief, 2013), and to enhance denitrification by enhancing the supply of $\mathrm{NO}_{\mathrm{x}}$ from both nitrification and the overlying water, and by increasing the area of interface between oxic and anoxic sediment zones (Bartoli et al., 2000; Welsh, 2003; Webb \& Eyre 2004; Dunn et al 2012). In the case of R. philippinarum direct transfer of oxygen and $\mathrm{NO}_{\mathrm{x}}$ from the water column to the burrow wall sediments would be limited to periods when the animal's withdraw their siphons during 
movement or in response to a perceived threat. During normal feeding behaviour the clam's siphons line the burrow, preventing direct transfer of oxygen and $\mathrm{NO}_{\mathrm{X}}$ between the circulated water and the burrow wall sediment (Nizzoli et al., 2006a). Oxygen, however can diffuse from the tissues of infaunal bivalves creating an oxidised sediment zone around their burrows (Pelegri \& Blackburn, 1995; Hansen et al., 1996), where nitrification could occur. The high rates of potential nitrification recorded in sediments surrounding bivalve siphons (Mayer et al., 1995) and associated with the outer shell surfaces of $R$. philippinarum (Welsh \& Castadelli, 2004) indicate that this oxygen supply is sufficient to support substantial rates of coupled nitrification-denitrification in the burrow wall sediments. However, whilst this mechanism would enhance rates of coupled nitrification-denitrification in the farmed sediment, our data suggest it is of secondary importance in comparison to the nitrification and denitrification rates directly associated with the clams themselves (See section 4.3).

Although, rates of both nitrification and denitrification were significantly and positively correlated with clam biomass, benthic denitrification efficiency was not significantly affected, as rates of sediment ammonification and effluxes of DIN to the water column were also stimulated to a similar degree as nitrification and denitrification rates. Consequently, whilst the high denitrification efficiency of the farmed sediments could be seen as being a buffer against eutrophication, the clam-farmed sediments remained a large source of DIN to the water column and therefore at the local scale clam farming adds to the eutrophication status of the farmed area. Additionally, any ecosystem service provided by increased denitrification rates was at least partially offset not only by the environmental costs of increased rates of nutrient regeneration, but also by increased emissions of the greenhouse gas $\mathrm{N}_{2} \mathrm{O} \cdot \mathrm{N}_{2} \mathrm{O}$ emissions were enhanced by increasing clam population density to a similar degree as nitrification and denitrification rates, as would be expected as $\mathrm{N}_{2} \mathrm{O}$ is a by-product of nitrification (Goreau et al., 1980; Poth \& Focht, 1985) and an intermediate in the process of 
denitrification (Zumft, 1997). The mean sediment $\mathrm{N}_{2} \mathrm{O}$ emission rate of $0.76 \mu \mathrm{mol} \mathrm{m} \mathrm{m}^{-2}$ was high, but still within the range typical of estuarine sediments, as was the mean $\mathrm{N}_{2} \mathrm{O}$ yield of $0.16 \%$ of total $\mathrm{N}_{2}+\mathrm{N}_{2} \mathrm{O}$ (Seitzinger \& Kroeze, 1998; Beaulieu et al. 2011). However, given the global extent of the farming of $R$. philippinarum and other filter-feeding bivalves, these relatively high $\mathrm{N}_{2} \mathrm{O}$ emission rates and $\mathrm{N}_{2} \mathrm{O}$ yields support the proposal of Stief (2013) that there is a need to assess the influence of bivalve aquaculture practises on $\mathrm{N}_{2} \mathrm{O}$ emissions.

\subsection{Microbial process rates and $\mathrm{N}_{2}$ Oemissions associated with isolated clams}

Significant rates of nitrification and denitrification were recorded associated with individual clams. High rates of nitrification have previously been reported associated with $R$. philippinnarum and other bivalves from both marine and freshwater environments (Welsh \& Castadelli, 2004; Svenningsen et al., 2012; Heisterkamp et al., 2013) with the bulk of this activity associated with biofilms colonising their shells, although other tissues, such as the siphons and gills can also be colonised (Welsh \& Castadelli, 2004). The shells and tissues of bivalves may represent a privileged site for nitrifying bacteria, as their hosts represent abundant sources of oxygen and $\mathrm{NH}_{4}{ }^{+}$, the substrates for nitrification. The essential role of the host in providing these substrates was clearly demonstrated in a previous study of $R$. philippinarum, where the shells of clams which had naturally died due to low water column salinity during a flooding event and decomposed for 5-7 days in the sediment no longer supported nitrification (Welsh \& Castadelli, 2004). Our data also support the hypothesis that there was a close relationship between the nitrifying bacteria and the clams, as estimated nitrification rates represented on average $48.9 \pm 4.1 \%$ of total clam $\mathrm{N}$-excretion indicating a tight coupling between these processes. Denitrification was also detected as $\mathrm{N}_{2}$ and $\mathrm{N}_{2} \mathrm{O}$ production during incubations of individual clams. To our knowledge this is the first report of denitrification associated with $R$. philippinarum, although denitrification has previously been 
detected in both shell biofilms and dissected guts of other bivalves (Svenningsen et al., 2012; Heisterkamp et al., 2010 \& 2013).

The determined $\mathrm{N}_{2} \mathrm{O}$ emission rate associated with clams of $0.38 \mathrm{nmol}$ g Fresh Weight ${ }^{-1}$ $\mathrm{h}^{-1}$ is similar to the average rate of 0.32 (range $0.02-5.45$ ) nmol g Fresh Weight ${ }^{-1} \mathrm{~h}^{-1}$ recorded for 20 marine invertebrates (Heisterkamp et al., 2010), with only one (Macoma balthica) of five bivalve species having a higher weight specific $\mathrm{N}_{2} \mathrm{O}$ production rate. In contrast, the relative yield of $\mathrm{N}_{2} \mathrm{O}$ of $0.97 \pm 0.29 \%$ of total $\mathrm{N}_{2} \mathrm{O}+\mathrm{N}_{2}$ is low compared to those of other marine molluscs of 13.4, 11.9 and 5.7\% of total nitrate reduced for Mytilus edulis, littorina littorea and Hinia reticulata (Heisterkamp et al., 2013). Thus, the high rates of $\mathrm{N}_{2} \mathrm{O}$ production determined for the isolated clams in this study were the result of the high rates of nitrification and/or denitrification associated with the clams rather than a high percentage yield of $\mathrm{N}_{2} \mathrm{O}$ in the emitted gaseous products of nitrification and denitrification.

High percentage yields of $\mathrm{N}_{2} \mathrm{O}$ associated with isolated benthic freshwater and marine invertebrates have generally been attributed to incomplete denitrification within the animal's digestive system (Stief et al., 2009; Heisterkamp et al., 2010; Stief \& Schramm, 2010; Svenningsen et al., 2012). It is proposed that denitrifying bacteria ingested by the animals in their diet are sourced primarily from oxic environments such as surficial sediments or the water column and that during the transition to the anoxic conditions in the gut- these bacteria fail to fully induce expression of nitrous oxide reductase, the enzyme that mediates the final step of denitrification process, the reduction of $\mathrm{N}_{2} \mathrm{O}$ to $\mathrm{N}_{2}$. This ultimately results in the accumulation and emission of $\mathrm{N}_{2} \mathrm{O}$ during denitrification of nitrate also ingested by the animals in their diet. Consequently, the low percentage yield of $\mathrm{N}_{2} \mathrm{O}$ determined in this study may indicate that the digestive system of $R$. philippinarum is not a significant site for denitrification. This may be as a result of the presence of bacteriolytic enzymes in the digestive system of $R$. philipinarum inhibiting denitrification by ingested bacteria, as has been 
suggested for Mytilus edulis (Heisterkamp et al., 2013) or simply that the diet of the sampled clams was poor in denitrifying bacteria, as diet has been shown to be a major determinant of gut denitrification and $\mathrm{N}_{2} \mathrm{O}$ emissions in freshwater invertebrates (Stief \& Schramm, 2010). The sampling site utilised in this study was located in the central marine zone of the Sacca di Goro lagoon and samples were collected during a period of calm weather, when the river Po was not in flood and the water column was not turbid. Thus, phytoplankton, which would not be expected to be heavily colonised by denitrifying bacteria may have been the major food source for the clams. However, during periods of rough weather and sediment resuspension, or when the river Po is in flood or in the more internal freshwater influenced clam-farmed areas of the lagoon and at other farmed sites throughout the World, food sources which would be expected to be richer sources of denitrifying bacteria such as detritus may contribute to the clam’s diet. Under these conditions, gut denitrification may be a more important process, which would be expected to increase overall $\mathrm{N}_{2} \mathrm{O}$ production rates of the clams and the percent contribution of $\mathrm{N}_{2} \mathrm{O}$ to total denitrification products. Thus, further studies are required to determine the effect of diet on gut denitrification and $\mathrm{N}_{2} \mathrm{O}$ production in R. philippinarum.

Since, it appears unlikely that gut denitrification was a significant contributor to the overall $\mathrm{N}_{2} \mathrm{O}$ emissions of the isolated clams, then it is probable that these were the result of nitrification and/or denitrification within biofilms colonising the clam's shells and/or their soft tissues. This proposal would be consistent with those of a recent study of $M$. edulis (Heisterkamp et al., 2013), where on average 95\% of $\mathrm{N}_{2} \mathrm{O}$ emissions emanated from shell biofilms with canonical denitrification and nitrifier denitrification contributing almost equally to overall $\mathrm{N}_{2} \mathrm{O}$ production. Further studies however, are required to localise the $\mathrm{N}_{2} \mathrm{O}$ sources associated with $R$. philippinarum and to determine the relative contributions of nitrification and denitrification to $\mathrm{N}_{2} \mathrm{O}$ production. 


\subsection{Potential contribution of clams to overall benthic process rates}

The estimates of the direct contributions of the clams to overall benthic respiration, ammonification, nitrification, denitrification and $\mathrm{N}_{2} \mathrm{O}$ emissions in each core were based on multiplying the rates determined during incubations of individual clams by the density of clams in each incubated core. These estimates therefore need to be regarded with degree of caution as the conditions during the clam incubations would differ from those in the sediment and may have affected microbial rates due to the changed availability of substrates $\left(\mathrm{O}_{2}, \mathrm{NH}_{4}{ }^{+}\right.$ and $\mathrm{NO}_{\mathrm{X}}$ ) and the physiology of the clams due to stress. The estimates should therefore be viewed as being indicative rather than truly quantitative.

The estimated respiratory oxygen demand of the clams in the individual cores could account for 70-281 (mean $133 \pm 22$ ) \% of total sediment oxygen demand. This overestimate, as discussed earlier may reflect the stressful conditions during the laboratory incubations, which probably elevated the clams respiration rate above that of the clams present in the sediment during the core incubations. This hypothesis is supported by a previous study by Dunn et al., (2009), where the respiration rates of amphipods, Victoriopisa australiensis was $\sim 40 \%$ greater for free-swimming compared to burrow inhabiting individuals during laboratory "bottle" incubations. In contrast, there was no significant difference between the $\mathrm{NH}_{4}{ }^{+}$ excretion rates of free-swimming and burrow dwelling individuals in the same study, indicating that the contribution of animal $\mathrm{N}$-excretion to overall sediment $\mathrm{N}$-regeneration rates may be a more reliable indicator of the contribution of animals to benthic metabolism. Nitrogen excretion by the clams in this study could account for on average $80 \pm 7 \%$ of benthic ammonification rates, indicating that the clams physiological rates were the major factor regulating organic matter turnover in the sediment. Given the very high biomass of clams in the farmed sediment, this estimate is in line with other estimates of the contribution of infauna N-excretion to sediment-water column $\mathrm{NH}_{4}{ }^{+}$or DIN fluxes, where the animals $\mathrm{NH}_{4}{ }^{+}$ 
excretion rates accounted for $10-90 \%$ of $\mathrm{NH}_{4}{ }^{+}$or DIN effluxes (Blackburn \& Henriksen, 1983; Gardner et al., 1993; Pelegri \& Blackburn, 1995; Magni et al., 2000; Dunn et al., 2009, 2012) with the highest contribution being for a Japanese tidal flat where the bivalves $R$. philippinarum and Muscilista senhousia dominated the natural faunal community (Magni et al., 2000). Overall, the potentially large contribution of clam respiration and N-excretion rates to SOD and ammonification rates, indicates not only that clams are a major influence on these rates, but that this effect is largely mediated by their own metabolism rather than by stimulating microbial respiration and N-mineralisation rates through the biodeposition of organic matter.

Nitrification and denitrification rates estimated for isolated clams accounted for on average 64 and $70 \%$ of the benthic rates in the cores incubations. Previous, studies have largely attributed the stimulation of benthic nitrification and denitrification rates by infauna to the increased availability of habitat for these bacteria in the animal's burrow walls (Bartoli et al., 2000; Webb \& Eyre, 2004; Nielsen et al., 2004: Satoh et al., 2007; Jordan et al., 2009; D’Andrea \& De Witt, 2009). In contrast, our results indicate that at least for infaunal bivalve species the animals themselves may provide an important and in the case of the studied clamfarmed sediment, the most important habitat for nitrifying and denitrifying bacteria in the sediment. However, it should be noted that this may represent an extreme case and that in other organisms such a polychaetes, which inhabit open irrigated burrows, the observed stimulations of nitrification and denitrification are likely, to a large extent due to the additional habitat provided for nitrifying and denitrifying bacteria by the burrow walls. Although, the fact that high rates of nitrification and denitrification have now been recorded associated with a wide functional and taxonomic range of infauna (Welsh \& Castadelli, 2003; Stief et al., 2009; Svenningsen et al., 2012; Heisterkamp et al., 2013; Stief, 2013), animal 
associated rates may make a significant contribution in many benthic ecosystems. Further study is required to elucidate this point.

Clams in addition to providing a habitat for nitrifiers and denitrifiers are also capable of supplying the $\mathrm{O}_{2}$ and $\mathrm{NH}_{4}{ }^{+}$required to sustain high rates of coupled nitrificationdenitrification. Thus, in situ in the farmed sediments, rates of nitrification, denitrification and associated $\mathrm{N}_{2} \mathrm{O}$ production may be relatively independent of environmental conditions, as they can largely be sustained by the clams own excretion of $\mathrm{NH}_{4}{ }^{+}$and $\mathrm{O}_{2}$. This hypothesis is supported by our laboratory incubations, where the N-excretion rate of the clams was more than sufficient to support all of the nitrification activity associated with the animals and this in turn was sufficient to sustain $~ 85 \%$ of the denitrification associated with the animals.

Estimates of $\mathrm{N}_{2} \mathrm{O}$ emissions from the sediment based on the population densities of clams in the each incubated cores consistently overestimated actual emission rates of the sediment with the estimated rates being on average $241 \%$ of the actual rate. This would suggest that the measured rates associated with isolated clams in the laboratory incubations were much greater than those associated with the clams in the sediment. It is possible however, that in fact rates associated with the clams in the core incubations were similar to those associated with the clams in the laboratory incubations and that in the more complex and heterogenous sediment environment there were sinks for the $\mathrm{N}_{2} \mathrm{O}$ produced, which moderated the $\mathrm{N}_{2} \mathrm{O}$ efflux to the overlying water. In a microcosm experiment, Stief and Schramm (2010) found that estimates of sediment-water column $\mathrm{N}_{2} \mathrm{O}$ fluxes based on rates of $\mathrm{N}_{2} \mathrm{O}$ production by denitrification in the gut of the mayfly (Ephemera danica) larvae were $155 \%$ of those actually measured in the microcosms and concluded that part of the $\mathrm{N}_{2} \mathrm{O}$ diffusing from the animals was consumed by microbial processes in the surrounding sediment. Therefore, it is possible that part of the $\mathrm{N}_{2} \mathrm{O}$ produced by nitrifying and denitrifying bacteria associated with the clams was also consumed by denitrifiers in the burrow wall sediments in our study. 
Overall, these estimates indicate that the direct effect of the clams through their own metabolism and that of the bacteria colonising them was the principal factor regulating benthic flux and process rates in the farmed sediments. This conclusion is also supported by the regression data shown in Table 2, as the slopes of these regressions (Change in flux/process rate g dry Flesh weight ${ }^{-1}$ ) are all highly similar to the rates measured during the laboratory incubations of isolated clams when these are also expressed on a per g dry Flesh weight $^{-1}$ basis (Table 3 ).

\section{Conclusions}

The population density of $R$. philippinarum was the major factor regulating all benthic processes and solute fluxes in the studied clam-farmed sediment. This effect was predominantly due to the direct influences of the clam's own metabolism and the activity of bacterial populations colonising the clams, as clam associated respiration, $\mathrm{N}$-excretion, nitrification and denitrification rates could explain on average $64-133 \%$ of SOD, and rates of ammonification, nitrification and denitrification in the core incubations. Therefore, in the studied sediment clams appear to regulate benthic processes primarily through their own metabolic activity and that of the bacteria that colonise them, rather than by stimulating microbial activities in the sediment via biodeposition of organic matter or the creation of favourable habitat in their burrow walls.

Rates of nitrification and denitrification associated with isolated clams were high and both the clams themselves and the farmed sediments were significant sources of the greenhouse gas $\mathrm{N}_{2} \mathrm{O}$. Although, this was largely due to the high rates of nitrification and denitrification, rather than high percentage yields of $\mathrm{N}_{2} \mathrm{O}$, as the $\mathrm{N}_{2} \mathrm{O}$ emissions of both the clams and the farmed sediment represented less than $1 \%$ of total $\mathrm{N}_{2} \mathrm{O}+\mathrm{N}_{2}$ production. 
The denitrification efficiency of the clam-farmed sediments was high, averaging 67.2 $\pm 9.9 \%$, but was not significantly influenced by clam population density, as benthic denitrification and ammonification rates, and sediment DIN effluxes were all enhanced to a similar degree by the population density of clams. Thus, whilst the high rates of denitrification per se and the high denitrification efficiency of the farmed sediments can be viewed as an ecosystem service, which mitigates the effects of nutrient loading to the lagoon, this ecosystem service comes at the environmental cost of increased inorganic- $\mathrm{N}$ regeneration and enhanced $\mathrm{N}_{2} \mathrm{O}$ emission rates within the farmed zones. It is therefore suggested that $\mathrm{N}$ regeneration rates and $\mathrm{N}_{2} \mathrm{O}$ emissions should be monitored in bivalve farmed areas and included in the impact assessments of current and future bivalve farming projects.

\section{Acknowledgments}

This study was supported with funding from Italian Ministry of University and Research, project PRIN 2008 no. 2008EZEFE4, “Nitrogen loads in the Po river basin: biogeochemical processes, transformations and effects in lowland reaches, transitional and coastal waters”.

\section{References}

APHA, 1998. Standard Methods for the Examination of Water and Wastewater, $20^{\text {th }}$ Edition. American Public Health Association, Washington D.C.

Bartoli, M., Nizzoli, D., Welsh, D.T., Viaroli, P., 2000. Short-term influence of recolonisation by the polychaete worm Nereis succinea on oxygen and nitrogen fluxes and denitrification: a microcosm simulation. Hydrobiologia 431, 165-174.

Bartoli, M., Nizzoli, D., Viaroli, P., Turolla, E., Castadelli, G., Fano, E.A., Rossi, R., 2001. Impact of Tapes philippinarum farming on nutrient dynamics and benthic respiration in the Sacca di Goro. Hydrobiologia 455, 202-212. 
Beaulieu, J.J., Tank, J.L., Hamilton, S.K., Wollheim, W.M., Hall, R.O., Mullholland, P.J., Petersen, B.J., Ashkenas, L.R., Cooper, L.W., Dahm, C.M., Dods, W.K., Grimm, N.B., Johnson, S.L., McDowell, W.H., Poole, G.C., Vallett, H.M., Arango, C.P., Bernot, M.J., Burgin, A.J., Crenshaw, C.L., Helton, A.M., Johnson, L.T., O’Brien, J.M., Potter, J.D., Sheibley, R.W., Sobota, D.J., Thomas, S.M., 2011. Nitrous oxide from denitrification in stream and river networks. Proceedings of The National Academey of Sciences USA 108, 214-219.

Blackburn, T.H., Henriksen, K., 1983. Nitrogen cycling in different types of sediments from Danish waters. Limnology and Oceanography 28, 477-493.

Bower, C.E., Hansen, T.H., 1980. A salicylate-hypochlorite method for determining ammonia in seawater. Canadian Journal of Fisheries and Aquatic Science 37, 794-798.

D’Andrea, A.F., De Witt, T.H., 2009. Geochemical ecosystem engineering by the mud Shrimp Upogebia pugetensis (Crustacea, Thalassinidae) in Yaquina Bay, Oregon. Density dependent effects on organic matter remineralization and nutrient cycling. Limnology and Oceanography 51, 1911-1932.

Dunn, R.J.K., Welsh, D.T., Jordan, M.A., Teasdale, P.R., Lemckert, C.J., 2009. Influence of natural amphipod (Victoriopisa australiensis) (Chilton, 1923) population densities on benthic metabolism, nutrient fluxes, denitrification and DNRA in sub-tropical estuarine sediment. Hydrobiologia 628, 95-105.

Dunn, R.J.K., Welsh, D.T., Jordan, M.A., Arthur, J.M., Lemckert, C.J., Teasdale, P.R., 2012. Interactive influences of the marine yabby (Trypaea australiensis) and mangrove (Avicenna marina) leaf litter on benthic metabolism and nitrogen cycling in sandy estuarine sediment. Hydrobiologia 693, 117-129.

FAO 2013 Global Aquaculture Production 1950-2011 http://wwwhttp://www.fao.org/fishery/statistics/global-aquacultureproduction/query/en 
Fenchel, T., King, G.M., Blackburn, T.H., 1998. Bacterial Biogeochemistry: the Ecophysiology of Mineral Cycling. Academic Press, San Diego. p. 307.

Fulweller, R.W., Brown, S.M., Nixon, S.W., Jenkins, B.D., 2013. Evidence and a conceptual model for the co-occurrence of nitrogen fixation and denitrification in heterotrophic marine sediments. Marine Ecology Progress Series 482, 57-68.

Gardner, W.S., Escobar Briones, E., Cruz Kargi, E., Rowe, G.T., 1993. Ammonium excretion by benthic invertibrates and sediment-water nitrogen flux in the Gulf of Mexico near the Mississippi River outflow. Estuaries 16, 799-808.

Goreau, T.G., Kaplan, W.A., Wofsy, S.C., McElroy, M.B., Valois, F.W., Watson, S.W., 1980. Production of $\mathrm{NO}_{2}{ }^{-}$and $\mathrm{N}_{2} \mathrm{O}$ by nitrifying bacteria at reduced concentrations of oxygen. Applied and Environmental Microbiology 40, 526-532.

Graf, G., Rosenberg, R., 1997. Bioresuspension and biodeposition: A review. Journal of Marine Systems, 11, 269-278.

Hansen, K., King, G.M., Kristensen, E., 1996. Impact of the soft-shell clam Mya arenaria on sulfate reduction in an intertidal sediment. Aquatic Microbial Ecology 10, 181-194.

Heisler, J., Glibert, P.M., Burkholder, J.M., Anderson, D.M., Cochlan, W., Dennison, W.C., Dortch, Q., Gobler, C.J., Heil, C.A., Humphries, E., Lewitus, A., Magnien, R., Marshall, H.G., Sellner, K., Stockwell, D.A., Stoeker, D.K., Suddleson, M., 2008. Eutrophication and harmful algal blooms: A scientific concensus. Harmful Algae 8, 3-13.

Heisterkamp, I.M., Schramm, A., de Beer, D., Stief, P., 2010. Nitrous oxide production associated with coastal marine invertibrates. Marine Ecology Progress Series 415, 1-9.

Heisterkamp, I.M., Schramm, A., Larsen, L.H., Svenningsen, N.B., Lavik, B., de Beer, D., Stief, P., 2013. Shell biofilm associated nitrous oxide production in marine molluscs: processes, precursors and relative importance. Environmental Microbiology 15, 19431945. 
Herbert, R.A., 1999. Nitrogen cycling in coastal marine ecosystems. FEMS Microbiology Reviews 23, 563-590.

Howe, R.L., Rees, A.P., Widdecombe, S., 2004. The impact of two species of bioturbating shrimp (Callianassa subterranean and Upogebia deltaurea) on sediment denitrification. Journal of the Marine Biological Association of the United Kingdom 84, 629-632.

Jordan, M.A., Welsh, D.T., Dunn, R.J.K., Teasdale, P.R., 2009. Influence of Trypaea australiensis population density on benthic metabolism and nitrogen dynamics in sandy estuarine sediment: a mesocosm simulation. Journal of Sea Research 61, 144-152.

Kana, T.M.C., Darkangelo, C., Hunt, M.D., Oldham, J.B., Bennett, G.E., Cornwall, J.C., 1994. Membrane inlet mass spectrometry for rapid high-precision of $\mathrm{N}_{2}, \mathrm{O}_{2}$ and $\mathrm{Ar}$ in environmental samples. Analytical chemistry 66, 4166-4170.

Keesing, J.K., Strzelecki, J., Fromont, J., Thomson, D., 2013. Sponges as an important source of nitrate on an oligotrophic continental shelf. Limnology and Oceanography 58, 19471958.

Kristensen, E., 2000. Organic matter diagenesis at the oxic/anoxic interface in coastal marine sediments, with emphasis on the role of burrowing animals. Hydrobiologia 426, 1-24.

Magni, P., Montani, S., Takada, C., Tsutsumi, H., 2000. Temporal scaling and relevance of bivalve nutrient excretion on a tidal flat of the Seto Inland Sea, Japan. Marine Ecology Progress series 198, 139-155.

Mayer, M.B., Schaffner, L., Kemp, W.M., 1995. Nitrification potentials of macrofauna tubes and burrow walls: effects of sediment $\mathrm{NH}_{4}{ }^{+}$and animal irrigation behaviour. Marine Ecology Progress Series 121, 157-169.

Nielsen, O.I., Gribsholt, B., Kristensen, E., Revsbech, N.P., 2004. Microscale distribution of of oxygen and nitrate in sediment inhabited by Nereis diverscolor: spatial patterns and estimated reaction rates. Aquatic Microbial Ecology 34, 23-32. 
Nizzoli, D., Welsh, D.T., Bartoli, M., Viaroli, P., 2005. Impacts of mussel (Mytilis galloprovincialis) farming on oxygen consumption and nutrient recycling in a eutrophic coastal lagoon. Hydrobiologia 550: 183-198.

Nizzoli, D., Welsh, D.T., Fano, E.A., Viaroli, P., 2006a. Impact of clam and mussel farming on benthic metabolism and nitrogen cycling, with emphasis on nitrate reduction pathways. Marine Ecology Progress Series 315, 151-165.

Nizzoli, D., Bartoli, M., Viaroli, P., 2006b. Nitrogen and phosphorus budgets during a farming cycle of the manila clam (Ruditapes philipinarum): an in situ experiment. Aquaculture 261, 98-108.

Nizzoli, D., Bartoli, M., Cooper, M., Welsh, D.T., Underwood, G.J.C., Viaroli, P., 2007. Implications for oxygen and nutrient fluxes and denitrification rates during during the early stage of sediment colonisation by the polychaete Nereis spp. in four estuaries. Estuarine Coastal and Shelf Science 75, 125-134.

Nizzoli, D., Welsh, D.T., Viaroli, P., 2011. Seasonal nitrogen and phosphorus dynamics during benthic clam and suspended mussel cultivation. Marine Pollution Bulletin 62, $1276-1287$.

Pelegri, S.P., Blackburn, T.H., 1995. Effect of bioturbation by Nereis sp., Mya arenaria and Cerastoderma sp. On nitrification and denitrification in estuarine sediments. Ophelia 42, 289-299.

Poth, M., Focht, D.D., 1985. ${ }^{15} \mathrm{~N}$ Kinetic analsis of $\mathrm{N}_{2} \mathrm{O}$ production by Nitrosomonas europaea: An examination of nitrifier denitrification. Applied and Environmental Microbiology 49, 1134-1141.

Quinn, G.P., Keough, M.J., 2002. Experimental design and data analysis for biologists. Cambridge University Press. 
Radax, R., Hoffmann, F., Rapp, H.T., Leininger, S., Schleper, C., 2012. Ammonia-oxidizing archaea as main drivers of nitrification in cold-water sponges. Environmental Microbiology 14, 909-923.

Robertson, D., Teasdale, P.R., Welsh, D.T., 2008. A novel gel-based technique for the twodimensional determination of iron (II) and sulfide in sediment. Limnology and Oceanography: Methods 6, 502-512.

Satoh, H., Nakamura, Y., Okabe, S., 2007. Influences of infaunal burrows on the community structure and activity of ammonia-oxidizing bacteria in intertidal sediments. Applied and Environmental Microbiology 73, 1341-1348.

Seitzinger, S.P., Kroeze, C., 1998. Global distribution of nitrous oxide production and N inputs in freshwater and marine ecosystems. Global Biogeochemical Cycles 12, 93-113.

Seitzinger, S., Harrison, J.A., Bohlke, J.A., Bouwman, A.F., Lowrance, R., Petersen, B., Tobias, B., Van Drecht, G., 2007. Denitrification across landscapes and waterscapes: A synthesis. Ecological applications 16, 2064-2090.

Smith, V. H., Schindler, D.W., 2009. Eutrophication Science: Where do we go from here? Trends in Ecology and Evolution 24, 201-207.

Stief, P., 2013. Stimulation of microbial nitrogen cycling in aquatic ecosystems by benthic macrofauna: mechanisms and environmental implications. Biogeosciencs 10, 2829-2846.

Stief, P., Schramm, A., 2010. Regulation of nitrous oxide emission associated with benthic invertibrates. Freshwater Biology 55, 1647-1657.

Stief, P., Poulsen, M., Nielsen, L.P., Brix, H., Schramm, A., 2009. Nitrous oxide emission by aquatic macrofauna. Proceedings of the National Academy of Sciences USA 106, 42964300.

Svenningsen, N.B., Heisterkamp, I.M., Sigby-Clausen, M., Larsen, L.H., Nielsen, L.P., Stief, P., Schramm, A., 2012. Shell biofilm nitrification and gut denitrification contribute to 
emission of nitrous oxide by the invasive freshwater mussel Dreissena polymorpha (Zebra mussel). Applied and Environmental Microbiology 78, 4505-4509.

Webb, A.P. and Eyre, B.D., 2004. Effect of natural populations of burrowing thalassinidean shrimp on sediment irrigation, benthic metabolism, nutrient fluxes and denitrification. Marine Ecology Progress Series 268, 205-220.

Welsh, D.T., 2003. It's a dirty job but someone has to do it: The role of marine benthic macrofauna in organic matter turnover and nutrient recycling to the water column. Chemistry and Ecology 19, 321-342.

Welsh, D.T., Castadelli, G., 2004. Bacterial nitrification activity directly associated with isolated marine animals. Marine Biology 144, 1029-1037.

Welsh, D.T., Bartoli, M., Nizzoli, D., Castaldelli, G., Riou, S.A., Viaroli, P., 2000. Denitrification, nitrogen fixation, community primary productivity and inorganic-N and oxygen fluxes in an intertidal Zostera noltii meadow. Marine Ecology Progress Series 208, 65-77.

Welsh, D.T., Dunn, R.J.K., Meziane, T., 2009. Oxygen and nutrient dynamics of the upside down jellyfish (Cassiopea sp.) and its influences on benthic nutrient exchanges and primary production. Hydrobiologia 635, 351-362.

Zumft, W.G., 1997. Cell biology and molecular basis of denitrification. Microbiology and Molecular Biology Reviews 61, 533-616. 
Table 1 Minimum, maximum and mean clam densities and biomass in the incubated cores (n = 10; figures in brackets indicate the standard error of the mean).

\begin{tabular}{|c|c|c|c|}
\hline & 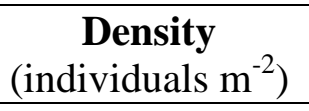 & $\begin{array}{c}\text { Total biomass } \\
\left(\mathrm{g} \text { fresh weight } \mathrm{m}^{-2} \text { ) }\right.\end{array}$ & $\begin{array}{c}\text { Flesh biomass } \\
\left(\mathrm{g} \text { dry weight } \mathrm{m}^{-2}\right)\end{array}$ \\
\hline Minimum & 400 & 1960 & 67 \\
\hline Maximum & 3400 & 15500 & 528 \\
\hline Mean & 1440 (313) & 7540 (1485) & $263(51)$ \\
\hline
\end{tabular}

Table 2 Relationships between clam biomass (g dry flesh weight $\mathrm{m}^{-2}$ ) per core, and benthic solute fluxes and estimated $\mathrm{N}$-cycle process rates $\left(\mu \mathrm{mol} \mathrm{m} \mathrm{m}^{-2} \mathrm{~h}^{-1}\right), \mathrm{n}=10$. Denitrification rates, $\mathrm{N}_{2}$ and $\mathrm{N}_{2} \mathrm{O}$ fluxes are expressed as $\mu \mathrm{mol} \mathrm{N}$.

\begin{tabular}{lccc}
\hline Flux/Process & $\begin{array}{c}\text { Slope } \\
\left(\mu \text { mol g dry flesh weight }{ }^{-1} \mathrm{~h}^{-1}\right)\end{array}$ & $\mathbf{R}^{2}$ & $\boldsymbol{p}$ \\
\hline $\mathrm{O}_{2}$ & -14.34 & 0.93 & $<0.001$ \\
$\mathrm{NO}_{\mathrm{x}}$ & -0.377 & 0.69 & 0.003 \\
$\mathrm{NH}_{4}^{+}$ & 1.255 & 0.89 & $<0.001$ \\
$\mathrm{DIN}$ & 0.867 & 0.75 & 0.001 \\
$\mathrm{~N}_{2}$ & 1.341 & 0.91 & $<0.001$ \\
$\mathrm{~N}$ & 0.003 & 0.55 & 0.013 \\
& & & \\
Denitrification & 1.345 & 0.91 & $<0.001$ \\
Nitrification & 0.973 & 0.80 & $<0.001$ \\
Ammonification & 2.218 & 0.92 & $<0.001$ \\
& & & \\
Denitrification efficiency & 0.009 & 0.02 & 0.664 \\
\hline
\end{tabular}


Table 3. Oxygen and dissolved N-species fluxes, estimated rates of nitrification, denitrification and $\mathrm{N}$-excretion, and \% contribution of $\mathrm{N}_{2} \mathrm{O}$ to denitrification $\left(\mathrm{N}_{2}+\right.$ $\mathrm{N}_{2} \mathrm{O}$ ) determined during incubations of individual clams. Data are shown as mean values $(n=5)$ with the standard error of the mean shown in brackets and standardised on a per individual (ind $\left.{ }^{-1}\right)$, per gram fresh weight $\left(\mathrm{g} \mathrm{FW}^{-1}\right)$ and per gram dry flesh dry weight ( $\mathrm{g} \mathrm{DW}^{-1}$ ) basis. All $\mathrm{N}$ species data are expressed as $\mu \mathrm{mol} / \mathrm{nmol} \mathrm{N}$.

\begin{tabular}{|c|c|c|c|}
\hline & $\mu \mathrm{mol} \mathrm{ind}{ }^{-1} \mathrm{~h}^{-1}$ & $\mu \mathrm{mol} \mathrm{g} \mathrm{FW}{ }^{-1} \mathrm{~h}^{-1}$ & $\mu \mathrm{mol} \mathrm{g} \mathrm{DW}{ }^{-1} \mathrm{~h}^{-1}$ \\
\hline \multirow[t]{2}{*}{$\mathrm{O}_{2}$ flux } & $-2.051(0.075)$ & $-0.402(0.026)$ & $11.816(0.847)$ \\
\hline & $\mathrm{nmol} \mathrm{ind}^{-1} \mathrm{~h}^{-1}$ & nmol g FW ${ }^{-1} h^{-1}$ & nmol g DW ${ }^{-1} h^{-1}$ \\
\hline $\mathrm{NO}_{\mathrm{x}}$ flux & $-34.1(1.9)$ & $-6.8(0.7)$ & -198.2 (19.3) \\
\hline $\mathrm{NH}_{4}^{+}$flux & $193.9(8.8)$ & $37.8(1.8)$ & 1111.9 (71.9) \\
\hline DIN flux & 159.7 (10.3) & $31(1.5)$ & $913.7(65.0)$ \\
\hline $\mathrm{N}_{2}$ flux & 232.9 (40.5) & $44.0(4.8)$ & 1297.9 (157.2) \\
\hline $\mathrm{N}_{2} \mathrm{O}$ flux & $1.9(0.4)$ & $0.4(0.1)$ & 11.5 (2.9) \\
\hline N-excretion & 394.7 (49.1) & $75.4(5.1)$ & 2223.2 (190.9) \\
\hline Denitrification & $234.9(40.4)$ & 44.2 (4.8) & 1309.5 (156.8) \\
\hline \multirow[t]{2}{*}{ Nitrification } & 394.7 (49.1) & $75.4(5.1)$ & 1111.3 9172.7) \\
\hline & $\%$ & & \\
\hline $\mathrm{N}_{2} \mathrm{O} / \mathrm{N}_{2}+\mathrm{N}_{2} \mathrm{O}$ & $0.9(0.29)$ & & \\
\hline
\end{tabular}




\section{Figure Legends}

Fig. 1. Map of Italy showing the location of the Sacca di Goro Lagoon in the Po river delta and the location of the study site $(\bullet)$ within the lagoon. The shaded area indicates the zones of the lagoon which are licensed for the farming of the Manila clam (Ruditapes philippinarum).

Fig. 2. Sediment-water column fluxes of oxygen, $\mathrm{DIN}, \mathrm{NO}_{\mathrm{x}}$ and $\mathrm{NH}_{4}{ }^{+}$determined for each individual core as a function of clam biomass ( $\mathrm{g}$ flesh dry weight $\mathrm{m}^{-2}$ ). Dashed lines indicate line of the linear regression analyses shown in Table 2.

Fig. 3. Sediment-water column fluxes of $\mathrm{N}_{2}$ and $\mathrm{N}_{2} \mathrm{O}$, and rates of nitrification and ammonification estimated by mass balance (See methods for details) for each individual core as a function of clam biomass ( $\mathrm{g}$ flesh dry weight $\mathrm{m}^{-2}$ ). Dashed lines indicate line of the linear regression analyses shown in Table 2.

Fig. 4. Mean rates of SOD, $\mathrm{N}_{2} \mathrm{O}$ emissions, ammonification and denitrification measured during core incubations and estimated quantitative and relative (\%) contribution of clam respiration and $\mathrm{N}$-excretion rates, and estimated clam associated nitrification and denitrification rates. The quantitative contribution of clams to overall benthic rates was calculated by multiplying the per individual rates determined in laboratory incubations (Table 3) by the density of clams in each core and calculating \% contribution of the clams to the overall rates for the same core. All data are given as mean values $(\mathrm{n}=10)$ and error bars indicate the standard error of the mean. All $\mathrm{N}$ 
species data are expressed as $\mu \mathrm{mol} \mathrm{N}$. Please note differences in the $\mathrm{y}$-axis scales between different panes of the figure. 
Fig 1.

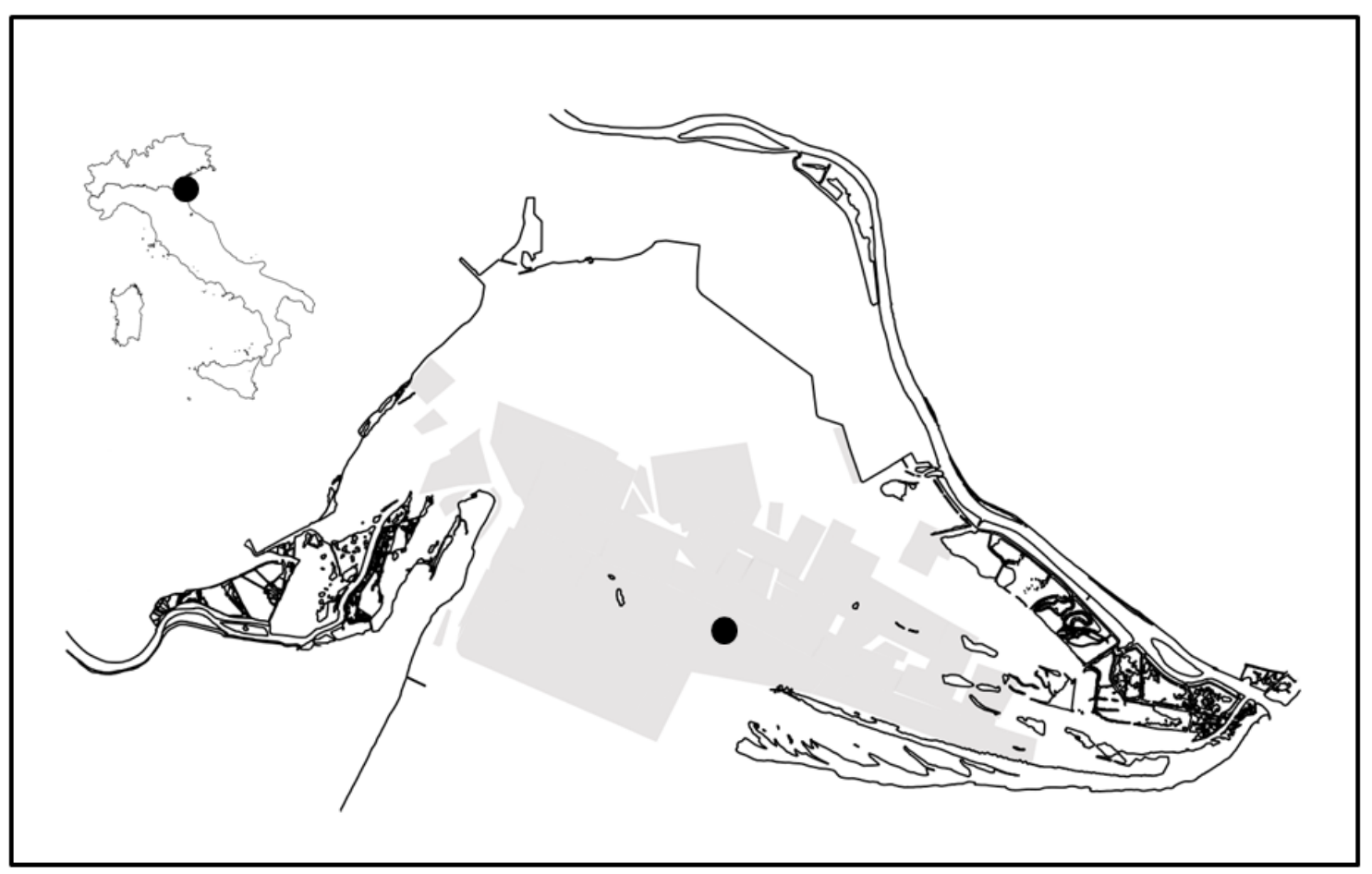


Fig. 2.
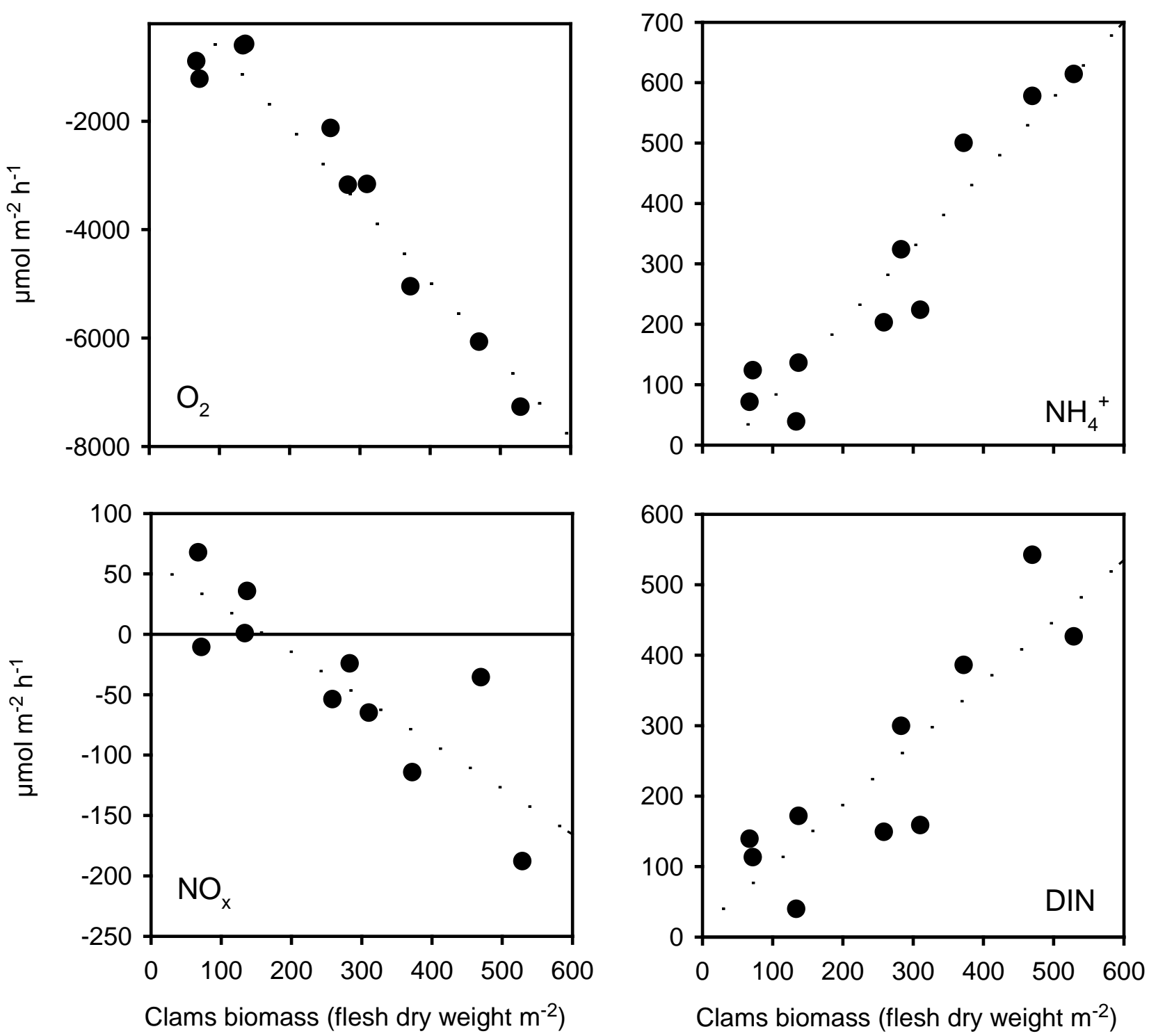
Fig. 3.
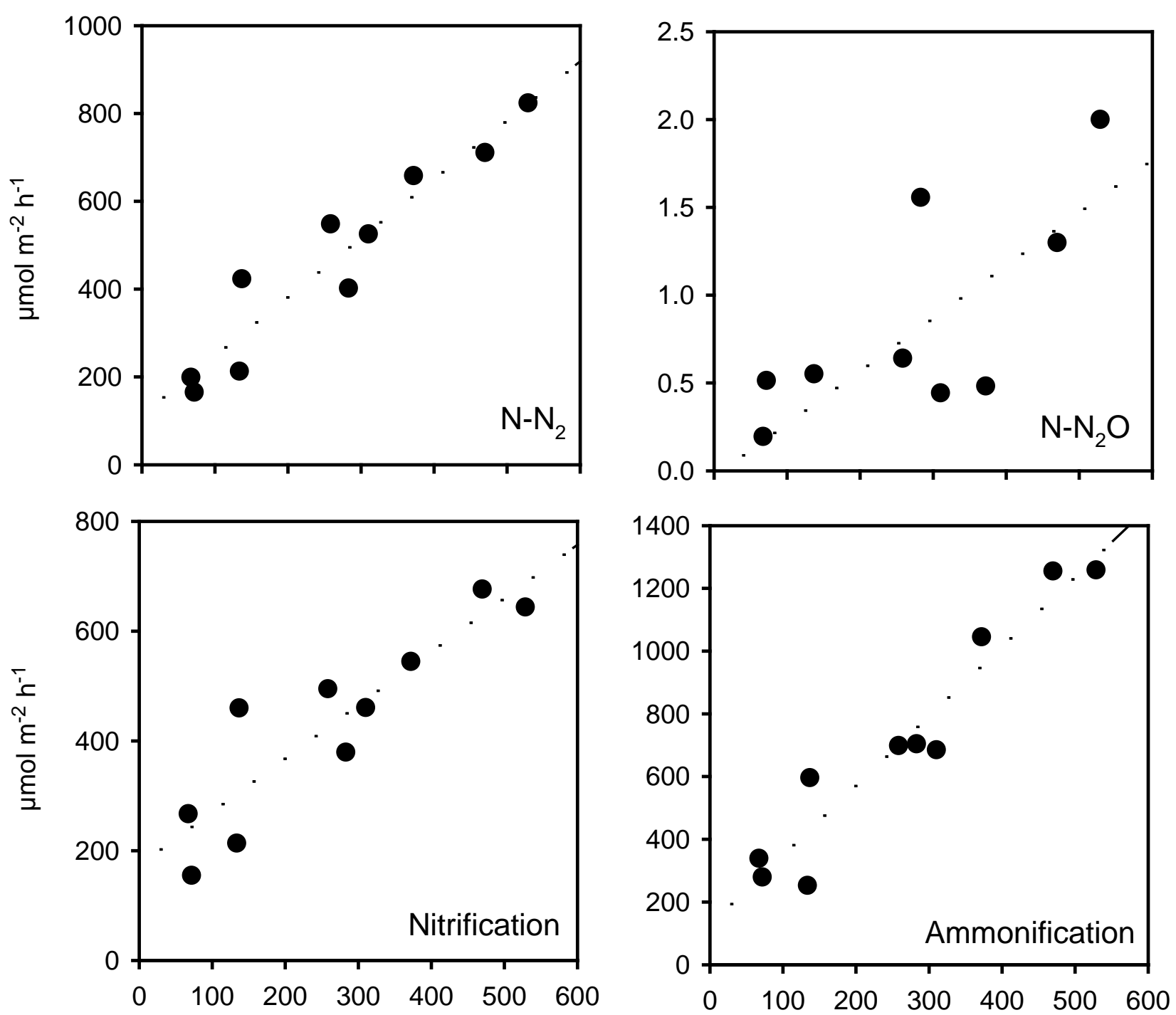

Clams biomass (flesh dry weight $\mathrm{m}^{-2}$ ) Clams biomass (flesh dry weight $\mathrm{m}^{-2}$ ) 
Fig. 4
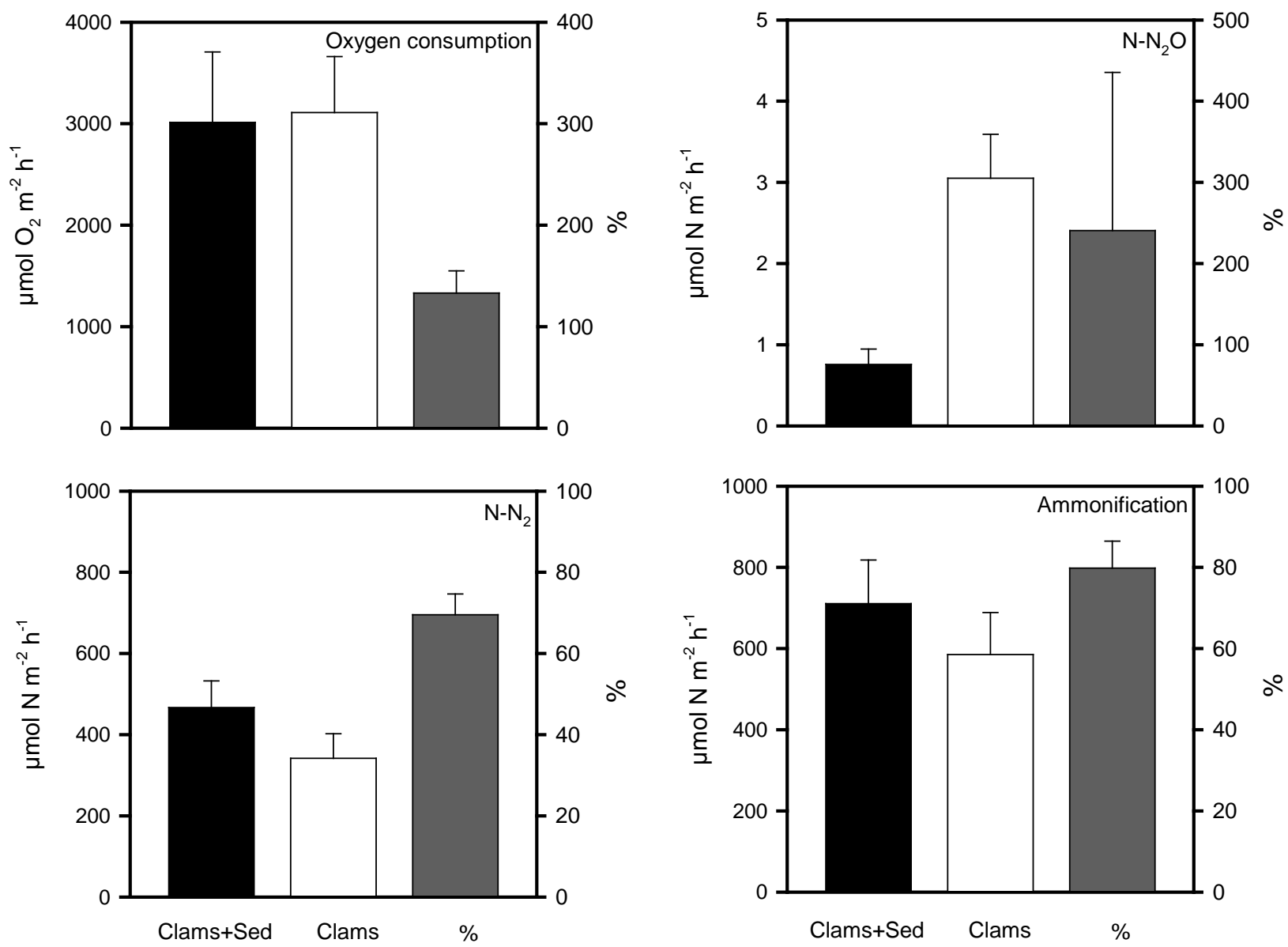